\title{
Single Women Involved in Entrepreneurship Negatively Affected by Gender and Marital Status as Entrepreneurs
}

\author{
Brown Chomba \\ Guidance and Counselling Department, Lusaka, Zambia
}

\begin{abstract}
Issues to do with gender imbalances and inequality of women in general and single women in particular in the political arena and entrepreneurship are nowadays a burning issue in all the countries worldwide. This is a major aspect of modern democratic governance such that low levels of female participation in politics are a major concern worldwide. The steps were taken by the United Nations Convention on stopping all forms of Discrimination against Women (CEDAW) and other international organizations have laid the concrete basis for the emergence of women's participation in politics and entrepreneurship. In Lusaka, Zambia, women's political participation is not proportional to the 50\% of the country's population which women represent, thereby not translating into equal representation in political leadership positions. The study employed questionnaires to collect data. The findings demonstrate that there exists a significant gender gap in the political participation of women in all the wards in the Lusaka district and that factors affecting their effective participation were social, economic, political, cultural, and religious-based. The study, therefore, recommended the change of perception of the people, equal representation in governance, support from everyone, and also stopping of discriminatory practices to ensure the equal and full participation of women.
\end{abstract}

Keywords: Capitalist, Challenges, Entrepreneurship, Gender imbalances, Political economy, Single women.

\section{Introduction}

Given good conditions, single women can run businesses, support their families and the community, and contribute to economic growth. The lack of single women's involvement in political and economic activities is a huge loss to the nation and society. Women make up 50.1 percent of the population in Zambia but are underrepresented in the Political and Economic sphere, largely due to social customs, religion, and cultural beliefs [1]. Society perceives Single women as too weak to conduct business and hold Political positions and prefers them to be confined to housekeeping activities and dependency on men [1]. Interestingly, the literature indicates that involving women in entrepreneurial activities helps in contributing to the development of national economies as well as economic empowerment of families [1] Despite this, women in Zambia have broken the barrier and started up a business and been seen taking up political positions. However, they face many challenges; their businesses and political activities remain small scale compared to their counterparts.

\section{Problem to be Solved}

Women entrepreneurship in Kenya is concentrated in the informed sector and small enterprises, totaling 612848 SMEs countrywide. This represents $47.4 \%$ of all SMEs in the country [2]. They face challenges like a lack of access to capital due to their inability to provide guarantees, with only $1 \%$ of women owning sufficient property to secure loans. They also face discrimination based on gender since lenders tend to ignore women; administration 
requires more paperwork of them to run their business, some city council officials deliberately delay the process and demand kick-backs or sexual favors. They face keen competition from male-owned businesses and find it difficult to manage male employees because of gender bias [2].

A study conducted in Kisii County in Kenya found that the challenges facing by female entrepreneurship included inadequate access to capital for start-up and growing business, administration issues, lack of guarantees to secure loans, and traditional cultural norms, beliefs, and practices [3]. However, Kenya has created a gender ministry to eradicate any form of discrimination based on sex to facilitate access to capital for women to launch and grow their businesses. Additional agencies have been created in order to promote women's entrepreneurship and enable women to compete locally and internationally [4].

For instance, the Kenyan government, in partnership with the USA has recently launched Women's Entrepreneurial centres of Resources, Education, access, and Training for Economic Empowerment (WECREATE), with the objective of helping women entrepreneurs to realize their business dreams; to close entrepreneurship gap between women and men, and to eradicate gender discrimination within entrepreneurship. They assist women in starting businesses, businesses, help women in the informed sector to move forward to the formal sector, converting their micro enterprises into small businesses. The centres provide capacity building, finance, coaching, and follow-up [5].

Despite these efforts, however, the support only extends to a small number of women entrepreneurs and has thus far done little to improve a lot of women entrepreneurs [6].

\section{Challenge Facing Women Entrepreneurship in South Africa}

Despite the role SA women play in socialeconomic development, they own $38 \%$ of all established businesses [7]. SA women entrepreneurs now represent $11 \%$ of all entrepreneurs, but most importantly, $78 \%$ of women entrepreneurs succeed against $70 \%$ of males [8]. Women entrepreneurs in Gauteng believe that they can conduct business even more successfully than males [9].

Nevertheless, they face challenges including a lack of adequate training and skills to face the business environment, a lack of access to capital, which pushes women to start business using their savings or borrowings from friends and relatives; stereotypes and patriarchal attitudes that discourage women from entering the business world, as well as a lack of family and community support, and insufficient acquaintance with new technology. All these things make it hard for women to compete against the strong experience and established businesses of men [9, 10] report that South African women entrepreneurs face challenges typical in developing countries: inadequate access to capital; limited access to markets, especially untapped ones; lack of information technology skills; inappropriate infrastructure, and lack of management and marketing skills. [11] Report that SA has begun to target women as an untapped force to synergize entrepreneurship. Various agencies such as the Small Enterprises Development Agency (SEDA). Small Enterprises Finance Agency (SEFA), the National Small business Council (NSBC), and the Department of Small Business Development (DSBD) were all created to help overcome challenges facing entrepreneurs, especially vulnerable youth and women. Yet it seems that women entrepreneurs are in fact less likely to benefit from these facilities than male entrepreneurs, who with established businesses are better placed to take advantage of what these agencies offer.

[11] argue that government support for SMMEs seems non-existent. Yet, since entrepreneurship offers a solution to unemployment and socio-economic development, the government and other stakeholders should allocate enough capital for 
SMMEs and pay attention to women's enterprises. Capacity-building should respond to the South Africa context, rather than simply implementing Western programmes that mostly fail in developing countries. [10] suggest that to encourage women entrepreneurship, the government should follow up with the implementation of policies and regulations that create a good business environment for start-up and growing, with lower interest rates, improved access to capital, and revision of taxes that cause women to quit the business and discourage prospective women entrepreneurs from starting new businesses.

\section{Constraints Experiencing Women Entrepreneurship in Rwanda}

Rwandan entrepreneurs face a range of challenges in the way of accelerating the growth of their business, the major one including energy (electricity), high tax rates, the high cost of transport, inadequate access to finance, highinterest rates, difficulties with tax administration, and the high cost of rent [12, 13] note that despite the efforts of Government of Rwanda (GoR) and the Private Sector Federation (PSF) to promote entrepreneurship, the industry still has problems, such as the cost of land, access to finance, cost of capital, taxes, and fiscal policy.

The World Bank [12] reports that Rwanda is landlocked, with poor infrastructure. The cost of electricity, transport, and telecommunication is high, which discourages international investors, particularly in the manufacturing industry. [13], the majority of female entrepreneurs run informal businesses; consequently, they cannot access finance and other opportunities available to SMMEs. They do not have enough information regarding business registration and other formalities, costs, and most importantly, the advantage of operating in the formal sector. They suggest that women should obtain the assistance of a lawyer or experts to register the business, but most of them cannot afford the cost.

\section{Challenges Single Women Face in doing Business in Kigali}

Female face similar challenges to male. However, women face extra specific challenges because of societal stereotypes [14, 12, 15]. These include inadequate access to finance, lack of collateral, a lot of taxes, high-interest rates, a lack of business management skills in the industry in which they are operating, a lack of business premises, which is why a considerable number of women run their business from home; difficulties with reaching a market for their products, especially those from rural areas; low consumer purchase capacity. Add to these the fact that they are operating with a society that encourages discrimination and inequality [13].

\section{Access to Finance}

Both men and women entrepreneurs face challenges with access to finance to sustain their businesses, but women more so [16, 17, 18]. Lenders distrust women's ability to run a successful business and prefer not to have women clients [19, 20, 21].

Women entrepreneurs secure smaller loans than men entrepreneurs, even if their businesses are performing better than those of their male counterparts [22, 23]. According to the Ministry of Gender and Family Promotion (MIGEPROF), Savings and Credit Cooperatives (SACCO Umurenge, micro-credit located in every country locality), women account for $23.80 \%$ of loans, compared to men with $66.30 \%$. In the past six years, the average percentage of loans obtained by women in Rwanda is $22.5 \%$, against $77.5 \%$ for men [23, 24]. Reports that men are applying for formal credit are more likely to benefit than women: $18.3 \%$ versus $12.5 \%$, respectively. For a comparison of credit products and services overall according to gender.

A short-term loan helps to move a business forward, but it is not sustainable at the same time as the business is being boosted; the payback period should therefore be extended [25, 26]. Some women are put off borrowing money because they are fearful of the high-interest rates 
$[18,23]$. Reports that entrepreneurs find that Micro Finance Institutions (MFIs) are more flexible than MFIs and 26\% form commercial banks.

The start-up, growth, and success of a business is associated with adequate access to finance and flexible interest rates and payback periods. However, the high interest rates charged by both commercial banks and micro-credit providers' impact on business development and discourage investors [27].

By way of comparison, South African interest rates between 1998 and 2016 averaged 12.9\%, enabling South Africa entrepreneurs to take advantage of credit to grow their businesses [28]. Tanzanian commercial banks give loans at an average interest rate of $15.83 \%$ [29].

\section{Education and Training}

Entrepreneurial education and training are critical tools for female entrepreneurs to manage a business successfully, not least because they update entrepreneurs on current and future business trends [30, 31, 32]. Education, skills, and experience in the industry with which an entrepreneur starts a business influence its chances of success [33].

Rwanda women's entrepreneurship suffers from a shortage of business managerial skills $[34,35]$. In Sub-Saharan Africa, less educated women with large families have little ambition beyond feeding and caring for their families. They believe that conducting a small business requires education and training that they do not have [35].

\section{Lack of Market}

A study conducted by women entrepreneurs' support projects in the Nyarugenge district in the city of Kigali showed that women entrepreneurs faced the challenge of a lack of market for their mushrooms. The mushroom production project is not only creating jobs and raising incomes, but it is also helping to eradicate malnutrition in the children of the project's members and the community as a whole [36]. These women do not have the marketing capacity to spot new markets or niche markets: they open for business in a saturated market where most businesses cannot survive the introduction phase of the business life cycle [37]. More women's businesses in Sub-Saharan Africa are forced to close down than men's businesses [35].

\section{Administration and Law}

Women entrepreneurs are anxious about the many requirements from government and local administrations for running a business; every single document they have to pay for they regard as an unnecessary expense [38, 39]. In India, many officials delay the licenses and other documents needed for business by women entrepreneurs in order to extract a bribe from them. This culture of corruption costs time and money and discourages would-be women entrepreneurs. [12], corruption in both public and private sectors is considerably lower in Rwanda than elsewhere in the region: Rwanda 4.35\%; Burundi $19.72 \%$; Uganda $23.57 \%$; Tanzania $51.11 \%$; and Kenya $73.8 \%$. In Kigali; Women entrepreneurs obtain rapid services from government officials without paying bribe.

Women are likely to keep their business working informally even if they are registered in the formal sector. They are afraid of hiring employees because it involves extra taxes as well as labour regulation. They prefer to work with family members who do not need contracts and are easy to fire. Family members earn less, make fewer demands, and are more trusted [13].

\section{Methods}

The study employed a descriptive design that utilized both qualitative and quantitative methods. Descriptive research aimed to accurately and systematically describe a population, situation, or phenomenon. It can answer what, where, when, and how questions, but not why questions. A descriptive research design can use a wide variety of research methods to investigate one or more variables. Unlike in experimental research, the researcher 
does not control or manipulate any of the variables but only observes and measures them. Descriptive research is an appropriate choice when the research aim is to identify characteristics, frequencies, trends, and categories. It is useful when not much is known yet about the topic or problem. Before you can research why something happens, you need to understand how, when, and where it happens. [40]. This is appropriate as it described the state of affairs as they exist. The researcher then reported the findings, which resulted to the formulation of important principles of knowledge. It involved the collection of information by interviewing or administering a questionnaire to a sample rather than the entire population at one point in time, which will range from one day to a few weeks. The study will employ this design to establish: challenges single women encounter in their pursuit to economically empower themselves, in Lusaka Zambia. The information gathered was summarized and interpreted to meet the purpose of the study.

\section{Sample Population}

The sample comprised 120 single women that was studied in groups and individually. The researcher drew a sample from single women of between 18 and 55 years. This allowed them to participate in the exercise with less difficulties in reading and participating in oral conversations. Thus the sample size for single women was as follows:12 single women came from the city market,12 single women will come from Kanyama market, 12 single women came from $\mathrm{St}$ Maurice Catholic church,12 single women came from Chabwino SDA Church,12 single women came from Indian Shops, 12 single women came from Zambian Open University,12 single women came from Kalundu multi-purpose cooperative, 12 single women will come from different political parties, and 12 Single women came from the general public that is the bus station.

\section{Questionnaires}

The required data was collected using questionnaires. The questionnaires was deemed suitable in that they have a large group of respondents; they have the benefit of selfadministrability, anonymity, and the standardization of questions for the purpose of easing the data analysis procedures [41]. The questionnaires were used to collect data from single women leaders in church and as well women group members.

They had both closed and open-ended questions to enable the researcher to collect data based on the objectives of the study. The questionnaires were hand-delivered to the respondents, who in turn will self-administer them.

\section{Existing Solutions for the Problems}

This then implies that women need to get involved in economic programmes of their choice if they have to get access and be in control of resources, thus becoming economically empowered. [42] have shown that women groups are key to women's earnings in rural areas. This suggestion is further highlighted by [43], who suggest that women groups are formed to address common economic problems that are not being met by existing organizations.

For instance, the Kenyan government, in partnership with the USA, has recently launched Women's Entrepreneurial Centres of Resources, Education, Access, and Training for Economic Empowerment (WECREATE), with the objective of helping women entrepreneurs to realize their business dreams; to close entrepreneurship gap between women and men, and to eradicate gender discrimination within entrepreneurship. They assist women to start businesses, help women in the informal sector to move forward to the formal sector, converting their micro enterprises into small businesses. The Centres provide capacity building, finance, coaching, and follow-up [2]. 
[44], women's enterprises in India continue to grow in a wide spectrum of industries, including engineering, Information technology, and telecommunication, food, tourism, business related to medicine, etc. this is because Indian women enrolled in sciences and engineering education which were considered before as men education, they have acquired an interest in entrepreneurship, where some of them perform better than men.

[45] argues that Rwandan government and stakeholder support for rural women's entrepreneurship through training and finance has had a positive impact on the success of women's enterprises. Other relevant organisations include Women for Health, which focuses on building the number of women entrepreneurs [64]. Africare is an international organization that supports 52 Rwandan women's associations with 3000 members, with the objective of developing women's enterprises [47]. The Rwanda Development Board (RDB) and PSF have created a fund for women entrepreneurship to support new enterprises and grow existing ones, but it seems that few women are aware of this [48].

\section{Which is the best one}

Of all the existing solutions for the problems, only one is found the best. For instance, Significant achievements have been scored through various initiatives to improve women's welfare in general and single women's access to soft loans, through banks, women empowerment schemes by the First lady Mrs. Esther Lungu and the President's Empowerment Initiatives Dr. Chagwa Lungu and the Ministry of Community Development. Women are able to receive a very substantial share to expand their enterprises sustainably.

\section{Limitations}

In Sub-Saharan Africa, less educated women with large families have little ambition beyond feeding and caring for their families. They believe that conducting a small business requires education and training that they do not have [35]. Some women are put off borrowing money because they are fearful of the high-interest rates [23].

[49], Islam does not allow women to interact with men, which means that Muslim women entrepreneurs suffer more from a lack of access to networks than other women entrepreneurs. Women entrepreneurs, particularly those in the rural areas, do not have enough information about local and international business, nor about business registration - which is why a significant number of them are in informal business [20, 33].

These women do not have the marketing capacity to spot new markets or niche markets: they open for business in a saturated market where most businesses cannot survive the introduction phase of the business life cycle [50].

Both inside and outside the country, women entrepreneurs face the problem of mobility, for example, to attend training, deal with networks, exhibit, and engage in other activities relating to business. Sometimes women using public transport women may fall victim to sexual harassment. Women's spouses and families do not like them to travel alone, which negatively impacts on their enterprises [51].

\section{Objectives}

This article intends to achieve the following objectives:

1. To improve the single women's life

2. To find solutions to many problems facing women

3. To enhance single women's chances to travel locally and internationally.

4. To cultivate the spirit of hard work

\section{Novelty of the Work}

The quality of work cannot be doubted; it has meet international standards. It is all rich in all departments. It has met all the requirements, so to speak. 


\section{Results}

The findings of the study have exposed problems that have to be solved in this respect; the government, NGOs, the community, and other stakeholders, including the single women themselves, need to work together in order to deploy the solutions to solve the problems that women are faced with. This is in line with the objectives outlined in the introduction, which are aimed at finding the solutions to the problems of women out there. And what the government and stakeholders are doing to solve their problems. The results are quite consistent with other researchers. Further, research would be necessary to answer the questions raised in the study. For instance, carrying out a comparative study of how women in rural areas are surviving and how their problems are being sorted out. The government, in partnership with the Ministry of Community Development, have come up with a lot of business ventures such as forming corporates, Social Cash Transfer, Presidential Initiative Empowerment. All these are meant to provide some solutions to solve women's impending problems. Women too are encouraged to be in the forefront and carry out economic activities with courage. The findings, for instance, sites the Kenyan government in partnership with the USA. The findings in Table 1 revealed that $64 \%$ [35] of respondents stated that high-interest rate was a challenge that women entrepreneurs faced in Lusaka, while the rest stated other challenges.

Table 1. Selected Challenges Women Face in Entrepreneurial Activities

\begin{tabular}{|l|l|l|}
\hline Challenges & Women & Percentage \\
\hline Inadequate access to finance & $\mathbf{9 2}$ & $\mathbf{8 8 \%}$ \\
\hline High interest rate & $\mathbf{6 7}$ & $\mathbf{6 4 \%}$ \\
\hline Collateral to obtain loan & $\mathbf{8 8}$ & $\mathbf{8 4 \%}$ \\
\hline High taxes & $\mathbf{6 4}$ & $\mathbf{6 1 \%}$ \\
\hline Lack of education and training & $\mathbf{7 8}$ & $\mathbf{7 4 \%}$ \\
\hline start-up capital & 95 & $90 \%$ \\
\hline High shop rentals & 71 & $68 \%$ \\
\hline Government regulations & 61 & $58 \%$ \\
\hline
\end{tabular}

\section{NB Some Women had more than One Challenges}

The women identified high-interest rates as a threat to their businesses. Interest rates scared them away from applying for loans and confined them to running their businesses using their own money. Having a small amount of working capital could inhibit the growth of their business. It appeared that the high-interest rate pushed women to look around for where they could borrow money without interest or at a reasonable rate of interest.

\section{Collateral to Obtain Loan}

A very high percentage of respondents, 88 $(84 \%)$, stated that collateral was a challenge facing single women in Lusaka. Efforts in Zambia had been made to grant women the right to own property, but there was still a long way to go. It seemed that women entrepreneurs wanted to own their own property to solve the issue of guarantees.

\section{Lack of Education and Training}

The results presented in Table 1 above show that $74 \%$ of respondents stated that a lack of education and training was a challenge facing women in Lusaka.

According to these responses, women entrepreneurs suffered as a result of not having the business skills and knowledge to run smart businesses. Respondents seemed to believe that if they had adequate education and training, they 
could have improved productivity and challenged male-owned businesses.

These findings were in line with what was reported by the United States Agency for International Development [52, 53], to the effect that sub-Saharan women entrepreneurship suffered from a lack of business education, skills, and training that impacted on their business continuity. [54] suggested that, in order to be successful, the training and education offered by foreign organisations should respond to the country's particular context instead of merely duplicating Western-style training, and that the Chamber of Women Entrepreneurs should play a significant role in training and the elaboration of curricula. [37] suggested that female entrepreneurs should receive appropriate education and training to enable them to face globalization and the speed of change in the macro-environment. [55] has shown that training given to female entrepreneurs in Nairobi was the catalyst for the growth of their businesses.

\section{Start-up Capital}

Most respondents (90\%) stated that start-up capital was a problem contributing to the low number of women entrepreneurs in Lusaka. It was apparent from this study that starting a business was difficult for single women because of the challenges they faced with obtaining startup capital unless they had the money themselves or could call on support from someone else. This situation indicated that banks and microfinancers did not lend start-up capital to women entrepreneurs because of the kinds of enterprises they operated.

Table 2. Selected Suggestions to Mitigate the Situation of Single Women Involvement in Entrepreneurship

\begin{tabular}{|c|c|c|c|c|}
\hline & Suggestions & Comments & Frequency & Percentage \\
\hline \multirow[t]{5}{*}{$A$} & \multirow{5}{*}{$\begin{array}{l}\text { Money lending institution } \\
\text { should relax conditions of } \\
\text { borrowing }\end{array}$} & Strongly Disagree & 0 & 0 \\
\hline & & Disagree & 0 & 0 \\
\hline & & Others & 8 & 7.6 \\
\hline & & Agree & 97 & 92.4 \\
\hline & & Total & 105 & 100 \\
\hline \multirow[t]{5}{*}{ B } & \multirow{5}{*}{$\begin{array}{l}\text { Government to facilitate women } \\
\text { to obtain finance to start and } \\
\text { grow business }\end{array}$} & Strongly Disagree & & \\
\hline & & Disagree & & \\
\hline & & Others & 20 & 19.1 \\
\hline & & Agree & 85 & 80.9 \\
\hline & & Total & 105 & 100 \\
\hline \multirow[t]{5}{*}{$\mathrm{C}$} & \multirow{5}{*}{$\begin{array}{l}\text { Government or church to come } \\
\text { up with training programmes for } \\
\text { single women }\end{array}$} & Strongly Disagree & & \\
\hline & & Disagree & & \\
\hline & & Others & 33 & 31.4 \\
\hline & & Agree & 72 & 68.6 \\
\hline & & Total & 105 & 100 \\
\hline \multirow[t]{5}{*}{$\mathrm{D}$} & \multirow{5}{*}{$\begin{array}{l}\text { Enacting laws that aim at } \\
\text { uplifting women business }\end{array}$} & Strongly Disagree & & \\
\hline & & Disagree & & \\
\hline & & Others & 16 & 15.3 \\
\hline & & Agree & 89 & 84.7 \\
\hline & & Total & 105 & 100 \\
\hline \multirow[t]{5}{*}{$\mathrm{E}$} & \multirow{5}{*}{$\begin{array}{l}\text { Increase a number of } \\
\text { cooperatives in communities }\end{array}$} & Strongly Disagree & & \\
\hline & & Disagree & & \\
\hline & & Others & 44 & 49.1 \\
\hline & & Agree & 61 & 58.1 \\
\hline & & Total & 105 & 100 \\
\hline
\end{tabular}




\section{Discussion}

\section{Government to Facilitate Women to obtain Finance to Start and Grow Business}

As Table 2 above further informs, $80.9 \%$ suggested the government needs to facilitate women to obtain finance to start and grow a business. This situation seemed to call for measures to ensure that the government and other stakeholders offered equal opportunities to all women entrepreneurs.

Respondents felt that accessibility to funding would greatly enhance their ability to carry out entrepreneurship activities, thus getting economically empowered. According to some respondents, the government availed funding, but unfortunately, the funding did not reach them. Therefore, there was a need to put mechanisms in place that ensured that all funding provided for the women reached the intended without fail.

The suggestions identified with the position taken by [56] who argued that the government, civil society, NGOs private sector and other relevant organs should step up awareness campaigns on empowerment of women and enhance awareness on the policy interventions already in place targeting single women.

\section{Government or Church to Come up with Training Programmes for Single Women}

As regards to this suggestion, $68.6 \%$ of the respondents stated that there was the need for the government or church to come up with training programmes for single women as this would increase their skills and knowledge on entrepreneurship.

This suggestion is shared by [80] that training programmes were important to the growth and empowerment of women. It was important to encourage women to participate in both national and international associations to share their experiences and expose them to local and international economic opportunities. Women could attend gender forums to showcase their undertakings on their specialization; this could help build on their self-confidence and selfesteem, as well as gain control over factors of production on an equal basis with men.

\section{Enacting Laws that aims at uplifting Women Businesses}

Some of the respondents felt that the reason as to why there was not much help with regards to economic empowerment was because most of the time, there were no laws aimed at uplifting women's business. According to some respondents $(84.7 \%)$, the government should enact laws aimed at uplifting women's business. It was for that reason that there was a need to put mechanisms in place that ensured that women, single women inclusive, were not left out.

\section{Increase a Number of Cooperatives in Communities}

In this regard, $58.1 \%$ of the respondents stated that there was the need for an increase in the number of cooperatives in communities. This, they felt, would enhance and empower them with entrepreneurship skills. The respondents suggested that there was the need for seminars and workshops that would train the single women on better ways of taking care of their businesses as well as gain information that would see them progress.

This identified with [57], who argued that partnering with local initiatives could help strengthen the women groups, and women could improve their households through such initiatives. For instance, in the pastoralist areas, livestock were a source of food security. Women empowerment through market participation assured the communities of access to food. Strategies to improve livestock value chains have always had the net effect of improving the community's welfare and bettering the capacities of women folk and their families [57]. 
Table 3. Below shows Challenges Single Women Faced in Politics

\begin{tabular}{|l|l|l|}
\hline Challenges & Number & Percentage \\
\hline Economic factors & $\mathbf{8 7}$ & $\mathbf{8 3 \%}$ \\
\hline Cultural and traditional norms & $\mathbf{7 6}$ & $\mathbf{7 2 \%}$ \\
\hline Political violence & $\mathbf{7 1}$ & $\mathbf{6 8 \%}$ \\
\hline Voter intimidation & $\mathbf{6 7}$ & $\mathbf{6 4 \%}$ \\
\hline Lack of ambition and confidence & $\mathbf{6 0}$ & $\mathbf{5 7 \%}$ \\
\hline Lack of education & 71 & $68 \%$ \\
\hline
\end{tabular}

\section{NB Some Women had more than One Challenges}

The above challenges are discussed as various subsections below;

\section{Economic Factors}

As earlier noted on challenges facing single women in politics, the main challenge in politics is lack of capital. $83 \%$ of the respondents felt inadequate financial resources posed as a challenge in the involvement of politics. According to some respondents, the socioeconomic status of women to a greater extent plays a significant role in enhancing their participation and representation in political decision-making bodies. In most communities' women were carrying a disproportionate share of domestic work.

\section{Conclusion}

This article has sought to contribute towards establishing how single women involved in entrepreneurship are negatively affected by their gender and marital status. Problems and solutions have been identified. This has not left any stone unturned. The study has recommended the change of perception of the people to look at women as equal partners in the development of the country economically. There is a need to encourage women to form corporative, because there is more power in working together than in working in isolation. There is sharing of ideas, new knowledge, skills, and above all teamwork that enhances profitability from whatever ventures they undertake. Women must strive to work hard with zeal and demonstrate that they are ready to uplift their economic status. Women, like men, should move forward and never allow themselves to remain behind. Women like men should be afforded the same opportunities as men. The evidence on the ground shows that although women are faced with numerous challenges, their future is bright because the world is moving to turn things around, soon and very soon, women will become the focus and the center of attraction in the world of business. The research has tacked and answered some of the questions as raised in the study.

\section{Acknowledgment}

I would like to express my profound gratitude to my supervisor Dr Atangambuyu Silungwe who has made an enormous contribution and self-sacrifice to the production of this article. Truly, it would not have been easy for me to produce this piece of work. Her feedback at every stage has been helpful. In a similar way, I would like to record my appreciation for the encouragement given to me by staff in the journal section of Texila American University. I am indebted to this team for the encouragement to make all the corrections in the article.

My special thanks, too, are extended to my beloved son and daughter Kabunda Chomba and Kasonde Chomba, who have offered their time and thought at different times to see to it that my manuscript is well-typed and edited.

\section{Conflict of Interest Statement}

The author, whose name is listed below, certifies that I have no affiliations with or 
involvement in any organizations or entity with any financial interest such as (honorary, education grants; participation in speakers bureaus; employment, consultancies, or other equity interest and expert testimony) or non-

\section{References}

[1] Noyoo.N 2008, Social Policy and human development in Zambia, Lusaka.Unza Press.

[2] Mwobobia. F .2012, The challenges facing small scale women entrepreneurs; A case of Kenya, International Journal of Business Administration.

[3] Osoro. K. Mokoro, A Nyamonga D and Areban 2013, constraints facing women Entrepreneurs in Kenya: A case study of micro and small enterprises in Kissi County.

[4] Omwenga. J Q, Mukulu E and Kanali 2013, Towards improving the performance of women entrepreneurs in small and medium enterprises in Nairobi County, Kenya Policy recommendations.

[5] Kavilu.S 2016, Kenya Women get support centreEast African Business.

[6] Evans. Klock, C, Demsenson, M and Musindo.A 2008, women entrepreneurs in Kenya factors affecting women entrepreneurs in Kenya Geneva International Labour organization.

[7] Mathonsi .C, (2013), Women's contribution to the economy; we cannot ignore the evidence.

[8] Marelise, 2015, Lindiwe Zulu: Conditions for South Africa's female entrepreneurs are criminals.

[9] Chinomona, E.Maziriri, E.T 2015, Women in action: challenges facing women entrepreneurs in the Gauteng province of South Africa. International Business and Economics Research Journal.

[10] Deborah. A.E, Wilhelmina S, Oyelana. A and Ibrahim, S.I 2015, Challenges faced by women entrepreneurs to ensure small business success in Nkonkobe Municipality Journal of Economics.

[11]Nxopo.Z and Iwu, C.G 2015, The unique obstacles of female entrepreneurship in the tourism industry in western cape, Unisa Press.

[12] World Bank. (2009), Female Entrepreneurship program guidelines and case studies.

[13] Stevenson. L and Stonge. A 2011, Assessment of environment for three developments of women's financial interest such as Personal or professional relationships, affiliations, knowledge, or beliefs) in the subject matter or materials discussed in this manuscript.

entrepreneurship in Cameroon, Mali, Nigeria, Rwanda and Senegal, Geneva: International Labour office.

[14]Zhu. L and Chu.H.M 2010.Motivations, success factors and problems encountered by Chinese women entrepreneurs; A factor analysis international Review of business Research papers.

[15]Choto.P, Tengeh. R and Iwu C 2014, Daring to survive or to grow? The growth aspirations and challenges of survivalist entrepreneurs in South Africa. Environmental economics.

[16] World Bank. 2011, Rwanda Country Profile.

[17] Rwanda, National Institute of statistics (2012), Access to Finance. Statistics-publication Vol 22012. [18] Fin Scope,2016, Financial inclusion in Rwanda. [19] The United States of America, United States Agency for International Development (2009), and Rwanda investing in the empowerment of women in a business report.

[20] Ayanone, 2011, Rwanda: tres peu des femmes dans les affaire.

[21]Blaire, 2015 Rwanda, s gender gap; Banks must stop failing female entrepreneurs.

[22] Fellmark, 2012, Focus on Rwanda. A conference on gender research and activist. Proceedings of the 2011 conference of the Kigali Institute of education, Kigali, Shirley Randell international and associates. [23] Finmark Trust. (2016), women and financial inclusion in Rwanda promoting greater financial inclusion of women in Rwanda.

[24] Igihe 2016, impossible rebattlement des taux d, intere du credit bancaire au Rwanda.

[25] Okafor and Amalu, 2012 Entrepreneurial motivations as determinants of women entrepreneurship challenges petroleum -Gas University of piolestine.

[26] Laeticia.M, Shukia, J and Luvanda, A 2015 microfinance and business growth of women small and medium enterprises in Rwanda. (A case of 
selected women and medium enterprises in Kicukiro district). European Journal of Accounting Auditing and Finance Research.

[27] Madictrie 2015, Heaven Kigali: Narrative and realities of an "ethnic minority" woman business owner. Kigali: institute for small businesses and entrepreneurs.

[28] Kganyago and Kazemi 2016, South Africa interest rate 1998-2016 Data/Chart/calendar/forecast. [29] Anon, 2016 Economic development; http: www.rwandapedia.rw/explore/economic development.

[30] Iwu.C. G and Nxopo. Z 2014, determining the specific support services required by female entrepreneurs in the South African tourism industry. African Journal of Hospitality. Tourism and leisure. [31]Chinomona, E. Maziriri, E.T 2015 Women in action: challenges facing women entrepreneurs in the Gauteng province of South Africa. International Business and Economics Research Journal.

[32] Lose.T and Tengeh R.K 2015, The sustainability and challenges of business incubators in the Western Cape Province, South Africa sustainability.

[33] Cutura. J 2008, Voices of Women Entrepreneurs in Rwanda, Washington: International Finance Corporation: Gender Program.

[34] United States Agency for international development 2009, Rwanda investing in the empowerment of women in a business report.

[35] Kelley. D.J Brush, C.G Greene P.G Litovsky Y.and GMRA 2012 Global entrepreneurship monitor 012 women's report Babson Global Entrepreneurship monitor.

[36] Muhayimana V.and Kimemia M 2015, Women Entrepreneurs support Projects and their contribution on the welfare of the beneficiaries in Rwanda case study Kigali city Province in Nyarugenge district, European Journal of Academic Essays.

[37] Odinga, O, E 2012 Challenges facing the growth of small and medium enterprises owned by women in Kakamenga Municipality, Master's thesis Nairobi. [38] Osoro, K Mokoro, A Nyamonga D and Areban 2013, constraints facing women Entrepreneurs in Kenya: A case study of micro and small enterprises in Kissi County.
[39] Siddiqui, A.B 2012, Problems encountered by women entrepreneurs in India. International Journal of Applied Research and Studies.

[40]Ngandu, K, Sophie. 2013. Writing a Research Proposal in Educational Research. The University of Zambia Press (UNZA PRESS), Lusaka.

[41] Orodho J A 2005, Elements of Educational and Social Sciences; Research methods Parents news online.

[42] Bureau 1980, Census of population and housing inter university consortium for political and social research.

[43] Mehta. H (2011) High yielding provenances of bhimal for fodder and fuel wood production in western Himalayas India.

[44] Kavilu.S 2016, Kenya Women get support centre-East African Business.

[45] Singh, R 2012, Women entrepreneurship issues, challenges and empowerment through self-help groups: An overview of Himachal Pradesh. International Journal of Democratic and Development Studies.

[46] Nyirazamani, A (2015), Evaluation of government support to the success of women entrepreneurs in selected rural districts of Rwanda. Master's thesis of University of Eastern Africa Baraton.

[47] International Finance Corporation (2008), Voice of women entrepreneurs.

[48] United States Agency for international development (2009), Rwanda investing in the empowerment of women in the business report.

[49]Fellman, A.C (2012), Focus on Rwanda: A conference on gender research and activist. Proceedings of the 2011 conference of the Kigali Institute of Education, Kigali. Shirley Randell International and Associates.

[50] Shahnawaz, M R 2015 Preliminary investigation of Emirati women entrepreneurship in the UAE: Motivating factors, challenges and government initiatives, International Journal of Applied Research.

[51] Odinga O.E 2012 Challenges facing growth of small and medium enterprises owned by women in Kakamenga Municipality, Master's Thesis, University of Nairobi. 
[52] United Nations 2014 empowering women entrepreneurs through information and communication technologies.

[53] Coldham, N.P. 2013, Empower Rwandan women Entrepreneurs: The gendered enterprises of nation-building. Master's thesis, Royal Roads University.

[54] Palaniappan, G Ramanigopal, C.S and Mani A 2012, A study on problem and prospects of women entrepreneurs with special reference to erode district. International Journal of Physical and Social Science.
[55] Wainana 2011, An equality perspective of education structure and performance in Kenya. University of Nairobi enterprises and services limited.

[56] Mahbub 2010, Human development in south Asia, Mahbub development centre.

[57] Njuki 2009, Women and livestock: a research initiative. A presentation to the intra household and Agricultural productivity Nairobi. 